\title{
Forum
}

Forum Policy: Members of the Association are invited to submit letters commenting on any article published in PMLA, or on matters of scholarly and critical interest to readers generally. Such letters, if accepted by the Editor, will be sent to the author of the work commented on, who will be invited to reply. The usual rules regarding courtesy and avoidance of personalities will be enforced, and the Editor reserves complete discretion in deciding whether or not to publish any letter. Letters should not exceed 1,000 words of text. Footnotes are discouraged and should be included only when absolutely necessary.

\section{Disguised Fiction}

To the Editor:

I am not writing to further attack Jean Wyatt, whose essay on Mrs. Dalloway ("Literary Allusion as Structural Metaphor," PMLA, 88, 1973, 440-51) was severely criticized by David Leon Higdon. But I would like to support Higdon's general thesis and to suggest, from the inside, so to speak, that the "scholarlycritical" approach to literature, at least as it is practiced by many people, rarely touches upon the creative work itself. Such articles are, in fact, disguised forms of fiction: they express certain ideas, feelings, speculations pertinent to the critic's state of mind at the time of the writing, but have little to do with the work itself. Thus, someone with a great knowledge of Dickens' work, let us say, will write a critical essay tracing the Dickensian influences in a certain writer ... someone whose background is in philosophy will "discover" many hidden philosophical influences in that same writer... someone who is working with the nouveau roman will discover parallels and "obvious" influences in the same writer. . . . and on and on, to infinity. Because I have a sense of humor, I have not been seriously disturbed by the bewildering and contradictory and, occasionally, quite mad "discoveries" made about my own writing. The dead-like poor Virginia Woolf-cannot defend themselves against critics who, armed with special grudges as if with special weapons, swarm in for the attack, the goal being, of course, the trophy of adding the article's title to the critic's bibliography, to be handed in to his departmental chairman. But a living author may, at least, make a few comments on the problem.

Most literary works are serious - but also playful. They may not exhibit the self-conscious, ingenious exuberance of Finnegans Wake, but they do allude, often, to other works - to the "tradition"--in a way that must, perhaps for want of a better term, be called playful. But a typical scholar-critic, especially a graduate student who is forced to come up with a "thesis" of some kind, will grimly seize upon one of perhaps fifty allusions or innuendos, and work with that to the exclusion of all else: the idea being to "prove" something about a work of art. But a work of art is primarily an experience, and there is nothing to be proven in terms of experience. One can "prove" that Wallace Stevens was to some extent influenced by Nietzsche-or by anyone at all, even writers he had not read - and yet it means nothing, ultimately. It does not make the poetry anything other than it is.

There was an MLA seminar devoted to "my" writing. I do not doubt the sincerity of "my" critics, and certainly they worked hard drawing conclusions, emphasizing parallels tracing influences, etc., etc.-not ever realizing, as I suspect most people in our profession do not realize, that they are expressing their own ideas and emotions, primarily, under the guise of objective criticism. Criticism is an art form--one should never forget that. It is deeply personal, always biased, sometimes eccentric and sometimes rather bland and derivative: but it is more an expression of the critic's mind than it is a description of the work of art itself. Even when allusions are playful and obvious, as in one of my novels-in which Alice in Wonderland, one of the novels of my childhood, figured heavily and deliberately - it is possible for the narrow, grimly rigid critic to overlook them, and snatch up other "allusions" which, in fact, do not exist. I was also amused and disturbed to see, in the same paper, dogged tracings of proper names back to their OE and IE roots, where of course they "mean" something-as what word does not?-when I had, deliberately, chosen names from a Detroit telephone directory in order not to choose symbolic, meaning-laden names. Perhaps it is cruel to say this, but one of the symptoms of the paranoid schizophrenic is his grim determination to see patterns and symbolic meanings everywhere, even in the arrangement of clouds in the sky. Yet, oddly, this same individual, overwhelmed by unconscious emotions which he cannot differentiate into consciousness (and sanity), will fail to see what meanings do exist-he is convinced that only his pattern, his private mythology is valid. Another symptom of emo- 
tional derangement is the ability-the more glib, the more suspect-to discern "parallel" plots and structures in two works. Critics do not generally know, as practicing writers do, that most plots are the expression of psychological developments ("beginnings," "middles," "ends") and relate to the individual psyche, rather than to the tradition of literature. In other words, one can make a very strong, convincing case for the influence of any writer on any other writer the influence, let us say, of Stendhal on Henry Fielding-because the development of plot, the use of a "hero," the introduction of innumerable symbolic factors, are simply common to the experience of writing any novel-and, in fact, of living any life. When a contemporary man falls in love, he may find himself writing love poems expressing the same emotions, even by way of identical images, that Renaissance love-poets used-without having read those poems. We are very, very communal people, sharing communal emotions, ideas, and dream-images, and of course literature reflects this.

There were many excellent seminars and discussion groups at the MLA: I know that the majority of teacher-critics in our profession are genuinely involved in the work of art, and in its tradition, and attempt to deal with literature in a nonreductivist, nonpedantic way. But I did notice a tendency, especially in younger people, to focus too narrowly upon a single strain or idea, and I would like to suggest to all who read this, who are involved in graduate work, that we make certain that our graduate students are not being mistrained. I am grateful to Higdon for his meticulous criticism of the Dalloway article; it would be well for us all to imagine a skeptical witness present as we write our papers and teach our classes. We have a responsibility (I am speaking as a professor now, who is involved with graduate students) to train our students to deal with the complexities of both literature and life, and never to encourage in them narrow, unrealistic methods of "criticism" that leave the work of art, as well as the world, untouched.

\section{Joyce Carol OATes \\ University of Windsor}

\section{Conrad, Wells, and the Two Voices}

\section{To the Editor:}

In broadening the context of his comparison between H. G. Wells and Conrad ("Conrad, Wells, and the Two Voices," PMLA, 88, 1973, 1049-65), Frederick Karl has offered a generally useful comparison between Wells and C. P. Snow. Snow's lectures on "The Two Cultures" are said to show the "breach" in Western culture between humanists, who have "faith in the power of folly," and scientists and logicians, who are dismayed by folly and wish "to order existence so that man's folly does not predominate." Karl's argument is of course praise of Dionysius over Apollo, and as such conventional; but he does Snow's lectures an injustice when he ranges the "two cultures" beside his own "two voices." The issue is worth raising because as poets like Blake and Yeats supplant the likes of Pope and Wordsworth in our pedagogy as representative Creative Men, Snow becomes a too convenient straw man-a spokesman for the outward-looking, optimistic, empirically minded, politically and bureaucratically knowledgeable fellows whom Blake naturally loathed and of whom Yeats complained that "the worst / Are full of passionate intensity," as they liberated Ireland.

But Snow is a dangerous straw man. Compared with Karl's "Two Voices," for instance, his "two cultures" distinction is admirably modest, a good man-ofaction's tool. It pretends to little analytic profundity. It accurately describes tensions in our institutions; it names the foolishness we may utter over the third or fourth drink with colleagues; and its validity disappears as we remember ourselves as thinkers. Karl's "voices," on the other hand, positively muffle what is best in his criticism. Thus, he writes impressively that while Wells turned to political liberalism, Conrad tested the "limits of logic and sanity," and finally

rejected science, rejected, indeed, most of civilization as mere veneer over man's barbarity, sought within individual isolation and loneliness for some code of behavior, some rule of morality that would, at least temporarily, give order to chaos, that would, for a time, cover over anarchy.

How is this magnificent inner voyage summarized? "In brief, he was arriving at a rarefied view of art, while Wells was ready to commit himself to social criticism." Surely Conrad had not arrived at a "rarefied" view, unless as with the medieval heavens that implies a more comprehensive and perfect view; but he had achieved a wisdom inherently personal. Humanism-meaning books--provided his instruments, but scarcely claims proprietary interest, any more than the scientist claims territorial rights over reason. Conrad's wisdom may have been lonely and skeptical, but it is ethically, anthropologically, and psychologically more rigorous than what Wells stood for: Conrad is scientifically better, if you will.

Karl's simplistic division misleads him in his final footnote in the same way. He quotes Joyce, who doubted whether Wells's "attitude toward words and language is as scientific as he himself ought to wish it to be." Joyce's words condemn Wells on behalf of scientific knowledge of language: yet Karl substitutes the opposite word, writing that "Joyce puts the argu- 